\title{
Lutowność tytanu w warunkach płomieniowego lutowania twardego pod osłoną topnika
}

\section{Titanium brazability in torch-heated conditions under the flux cover}

\section{Streszczenie}

W artykule przedstawiono podstawowe problemy związane z lutowaniem tytanu w osłonie topnikowej. Podano mechanizm fizykochemicznego oddziaływania topników na powierzchni tytanu podczas procesu lutowania. Zamieszczono wyniki badań recepturowo-technologicznych, realizowanych w Instytucie Spawalnictwa w Gliwicach, nad specjalistycznym topnikiem do płomieniowego lutowania twardego. Omówiono właściwości lutownicze topnika oraz przedstawiono badania metalograficzne połączeń wykonanych z jego użyciem.

\section{Wstęp}

W ostatnich latach można zaobserwować zwiększone zainteresowanie wyrobami wykonanymi z tytanu oraz jego stopów. Związane jest to przede wszystkim ze stawianiem coraz większych wymagań materiałom eksploatacyjnym pod względem wytrzymałości mechanicznej, termicznej, twardości, przewodności elektrycznej czy odporności chemicznej (korozyjnej) na niekorzystne warunki środowiskowe.

Tytan zaliczany jest do „przyszłościowych” metali głównie dzięki swoim wyjątkowym właściwościom fizycznym i mechanicznym, takim jak: duża odporność temperaturowa i korozyjna, mała gęstość oraz duża wytrzymałość mechaniczna (tabl. I). Wykorzystywany jest $w$ wielu nowoczesnych i innowacyjnych wyrobach oraz urządzeniach. To właśnie dzięki swoim właściwościom eksploatacyjnym tytan oraz jego stopy znajdują coraz większe zastosowanie zarówno

Prof. dr hab. inż. Zbigniew Mirski - Politechnika Wrocławska, mgr inż. Dawid Majewski - Instytut Spawalnictwa w Gliwicach. w najnowocześniejszych gałęziach przemysłu i gospodarki, jak i w produkcji sprzętu i implantów medycznych, sprzętu sportowego, wyrobów jubilerskich i galanterii metalowej $[1 \div 7]$.

W porównaniu $z$ innymi nowoczesnymi materiałami konstrukcyjnymi tytan oraz jego stopy jako materiał

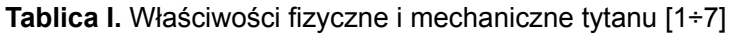
Table I. Physical and mechanical properties of titanium $[1 \div 7]$

\begin{tabular}{|c|c|}
\hline Struktura krystaliczna & $\begin{array}{l}\alpha-\mathrm{Ti}\left(H Z^{*}\right) a=0,295 \mathrm{~nm}, \\
\mathrm{c}=0,468 \mathrm{~nm}, \mathrm{c} / \mathrm{a}=1,6 \mathrm{w} 25^{\circ} \mathrm{C} \\
\beta-\mathrm{Ti}\left(\mathrm{RSC}^{*}\right) a=0,332 \mathrm{~nm} \\
\mathrm{w} 900^{\circ} \mathrm{C}\end{array}$ \\
\hline Gęstość, $\rho, \mathrm{kg} / \mathrm{dm}^{3}$ & 4,48 \\
\hline Temperatura topnienia, $\mathrm{T}_{\mathrm{t}},{ }^{\circ} \mathrm{C}$ & 1670 \\
\hline Przewodnictwo cieplne, $\mathrm{y}, \mathrm{W} / \mathrm{m} \cdot \mathrm{K}$ & 21,6 \\
\hline $\begin{array}{l}\text { Współczynnik rozszerzalności ciepl- } \\
\text { nej }\left(0-100^{\circ} \mathrm{C}\right), \alpha, \mathrm{K}^{-1}\end{array}$ & $8,5 \cdot 10^{-6}$ \\
\hline Moduł sprężystości wzdłużnej, E, GPa & 110 \\
\hline Wytrzymałość na rozciąganie, $\mathrm{R}_{\mathrm{m}}, \mathrm{MPa}$ & $>240$ \\
\hline Wydłużenie względne, A5, \% & 24 \\
\hline \multicolumn{2}{|c|}{$\begin{array}{l}\text { * HZ - sieć heksagonalna zwarta, RSC - sieć regularna ściennie } \\
\text { centrowana }\end{array}$} \\
\hline
\end{tabular}


lekki wyróżniają się dużą wytrzymałością względną (stosunek wytrzymałości do gęstości) w szerokim zakresie temperaturowym. Wytrzymałość względna stopów tytanu jest ok. 1,5 razy większa od wysokowytrzymałych stali stopowych. Wytrzymałość względna innych stopów metali lekkich, np. Al lub Mg, również ustępuje sto-

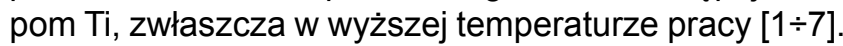

\section{Lutowność tytanu}

Tytan charakteryzuje się dużym powinowactwem chemicznym prawie do wszystkich pierwiastków, a zwłaszcza do gazów występujących w powietrzu, takich jak: tlen, azot i wodór. W powietrzu tytan utlenia się stosunkowo wolno, jednakże powstający podczas nagrzewania trwały tlenek $\mathrm{TiO}_{2}$ jest podstawowym utrudnieniem procesu lutowania. Intensywność powstawania tego tlenku jest szczególnie duża w temperaturze $650 \div 700^{\circ} \mathrm{C}$.

Przy nagrzewaniu elementów wykonanych z tytanu i jego stopów do temperatury powyżej $900^{\circ} \mathrm{C}$ w atmosferze powietrza, na ich powierzchni powstają także azotki tytanu, powodujące kruchość. Z wodorem tytan o odmianie alotropowej a tworzy kruche wodorki, natomiast w odmianie dwufazowej tytanu $(\alpha+\beta)$ wodór rozpuszcza się w większym stopniu $[2,4,5]$.

Prawie ze wszystkimi metalami stosowanymi jako podstawowe składniki lutów twardych $(\mathrm{Cu}, \mathrm{Ni}, \mathrm{Fe}, \mathrm{Ag}$, $\mathrm{Si}, \mathrm{Al}$ ) tytan tworzy fazy międzymetaliczne, wydzielające się często na granicach lutowiny w postaci ciągłych, twardych i kruchych warstw, co zmniejsza właściwości wytrzymałościowe i plastyczność połączeń lutowanych $[2,4,5]$.

Obecnie lutowanie twarde odpowiedzialnych elementów wykonanych z tytanu i jego stopów wykonuje się wyłącznie w próżni lub w czystych atmosferach kontrolowanych, neutralnych chemicznie. Jednakże w przypadku, gdy lutowany element wykonany z tytanu ma dość znaczne gabaryty, lub stanowi element konstrukcji o większych wymiarach gabarytowych, nie jest możliwe przeprowadzenie procesu lutowania w piecu. Również lutowanie mniej odpowiedzialnych mechanicznie wyrobów wykonanych z tytanu, takich jak: biżuteria, galanteria metalowa (sprzęt oświetleniowy, oprawki okularów itp.) nie musi być wykonywane w specjalistycznych piecach próżniowych. Do lutowania tych elementów w atmosferze powietrza zalecane jest zastosowanie wysokoaktywnego, specjalistycznego topnika lutowniczego, który zapewni wymaganą zwilżalność i rozpływność lutu na materiałach łączonych oraz prawidłowe wypełnienie kapilarnych szczelin lutowniczych. Działanie topnika obejmuje również redukcję chemiczną i roztwarzanie warstw tlenkowych na powierzchni materiałów łączonych i lutu, a także zapobieganie ich ponownemu utlenieniu podczas całego procesu lutowania. Ponadto topnik ten powinien również zmniejszać napięcie powierzchniowe lutu $[2,4,5,9]$.

\section{Lutowanie twarde tytanu w powietrzu z zastosowaniem topników}

\section{Ogólne wymagania stawiane topnikom}

Do procesu lutowania twardego tytanu w atmosferze powietrza niezbędne jest zastosowanie wysokoaktywnych, specjalistycznych topników lutowniczych. Są to substancje i preparaty chemiczne, które w procesie lutowania $\mathrm{w}$ atmosferze powietrza zapewniaja prawidłowy przebieg procesu lutowania. Podstawowe wymagania stawiane topnikom lutowniczym to przede wszystkim $[4,8,10,11]$ :

- temperatura topnienia i aktywności (temperatury te na ogół się pokrywają) nieco niższa, a temperatura parowania odpowiednio wyższa od temperatury topnienia lutu,

- równomierne rozpływanie się w temperaturze lutowania po powierzchniach łączonych materiałów i dobre wnikanie do kapilarnych szczelin lutowniczych,

- skuteczna aktywność chemiczna w temperaturze lutowania i nieco poniżej oraz zdolność wiązania tlenkowych związków niemetalicznych na powierzchniach łączonych materiałów i lutu,

- ochrona złącza przed działaniem gazów atmosfery procesu (powietrza),

- tworzenie łatwo usuwalnego żużla i pozostałości wypływających na powierzchnię ciekłego lutu podczas powstawania połączenia lutowanego,

- trwałość składu chemicznego i postaci w warunkach magazynowania,

- zapewnienie możliwie najkorzystniejszych warunków bhp podczas lutowania.

\section{Mechanizm fizykochemicznego oddziaływania topników na powierzchni tytanu podczas procesu lutowania}

Topniki lutownicze stosowane podczas lutowania twardego tytanu w atmosferze powietrza muszą spełniać jeszcze jeden z podanych poniżej warunków $[4,5]$ :

- usuwać niezwilżalną przez luty warstewkę tlenku i azotku tytanu przez absorpcję lub jej chemiczne roztwarzanie,

- oddziaływać aktywnie na powierzchnię metalu pod warstwą tlenków i azotków, wskutek czego warstwa ta jest usuwana podczas płynięcia lutu.

Po spełnieniu jednego z powyższych warunków, przynajmniej jeden ze składników topnika powinien wchodzić w reakcję z tytanem, wykorzystując jego zdolność do redukcji metali z roztopionych soli. Powierzchnia tytanu zostaje pokryta wówczas 
warstewką zredukowanego metalu, który zapobiega dalszemu utlenianiu, wg równania:

$$
\mathrm{nMe}_{\mathrm{p}}+\mathrm{mMe}_{\mathrm{t}} \mathrm{Xn} \rightleftarrows \mathrm{nMe}_{\mathrm{p}} \mathrm{X}_{\mathrm{m}}+\mathrm{mMe}_{\mathrm{t}}
$$

gdzie: $\mathrm{n}, \mathrm{m}$ - współczynniki stechiometryczne, $\mathrm{Me}_{\mathrm{p}}$ - metal lutowany, $\mathrm{Me}_{\mathrm{t}}-$ metal w składzie topnika, $\mathrm{X}$ - grupa fluorowa

\section{Dotychczasowy stan zagadnienia}

Większość dostępnych na rynku topników, zalecanych do lutowania twardego różnych metali, nawet tych o najtrwalszych tlenkach, jest nieprzydatna w przypadku lutowania tytanu, gdyż nie zapewniają one właściwej ochrony tego reaktywnego metalu przed utlenieniem w temperaturze lutowania, a zatem nie stwarzają prawidłowych warunków zwilżenia lutem powierzchni łączonych elementów.

W literaturze specjalistycznej z zakresu lutowania rzadko można znaleźć skład chemiczny topników do lutowania płomieniowego lub indukcyjnego tytanu w powietrzu. Przykłady opracowanych składów chemicznych topników w \% wag. podano poniżej $[4,9,11]$ :

- $45 \% \mathrm{NaCl}, 36 \% \mathrm{KCl}, 10 \% \mathrm{AgCl}, 9 \% \mathrm{LiF}$,

- $50 \% \mathrm{KF}, 46 \% \mathrm{LiF}, 4 \% \mathrm{AgCl}$,

- $50 \% \mathrm{LiCl}, 25 \% \mathrm{KF}, 25 \% \mathrm{MgCl}_{2}$.

Topniki te, jak wykazały próby lutowania przeprowadzone w Instytucie Spawalnictwa, nie zapewniają dobrych właściwości lutowniczych dla spoiw srebrnych w przypadku łączenia tytanu (mała rozpływność lutów), a także charakteryzują się bardzo małą trwałościa.

\section{Topnik F60T do twardego lutowania tytanu w powietrzu}

W celu wyeliminowania tych wszystkich niedogodności, w 2010 r. w Instytucie Spawalnictwa podjęto pracę badawczą mającą na celu otrzymanie topnika do twardego lutowania tytanu w powietrzu, charakteryzującego się dużą aktywnością chemiczną, dobrą zwilżalnością materiału podstawowego oraz dużą trwałością chemiczna [12].

W trakcie badań recepturowych nad topnikiem do twardego lutowania tytanu w atmosferze powietrza opracowano i przygotowano w skali laboratoryjnej 80 receptur chemicznych topników, zmieniając sukcesywnie ich skład chemiczny w wyniku weryfikacji temperatury topnienia i właściwości lutowniczych.

Opracowano topnik o oznaczeniu F60T, na bazie związków chemicznych takich jak: $\mathrm{KF} \cdot 2 \mathrm{H}_{2} \mathrm{O}$, $\mathrm{KHF}_{2}$, LiCl oraz $\mathrm{ZnCl}_{2}$. Aby móc w pełni ocenić aktywność, skuteczność oraz trwałość topnika, przeprowadzono:

- analizę profilową stopionego topnika, potwierdzającą mechanizm powstawania warstwy cynkowej na powierzchni tytanu (zgodnie z równaniem 1),
- badania rozpływności lutu srebrnego na podłożu tytanowym,

- badania właściwości mechanicznych złączy wykonanych z zastosowaniem topnika F60T.

Ponadto określono również wstępną trwałość chemiczną topnika, która na podstawie oceny właściwości lutowniczych wyniosła 12 miesięcy [12].

\section{Analiza profilowa stopionego topnika}

W celu potwierdzenia przewidywanego mechanizmu powstawania warstwy metalu zredukowanego na tytanie (równanie 1) przeprowadzono analizę profilową z wykorzystaniem optycznego spektrometru emisyjnego GDS 850A firmy LECO. Jako podłoże (próbka o wymiarach 40 × 40 × 2,5 mm) zastosowano blachę tytanową Grade 2 wg ASTM B265. Na podłoże tytanowe nanoszono 0,2 g topnika, następnie poddawano je ogrzewaniu od dołu stacjonarnym palnikiem acetylenowo-tlenowym z nasadką o wydajności $160 \mathrm{dm}^{3} \mathrm{C}_{2} \mathrm{H}_{2} / \mathrm{h}$. Nagrzewanie przerywano po $3 \mathrm{~s}$ od momentu stopienia topnika. Na rysunku 1 pokazano wynik analizy profilowej stopionego topnika.

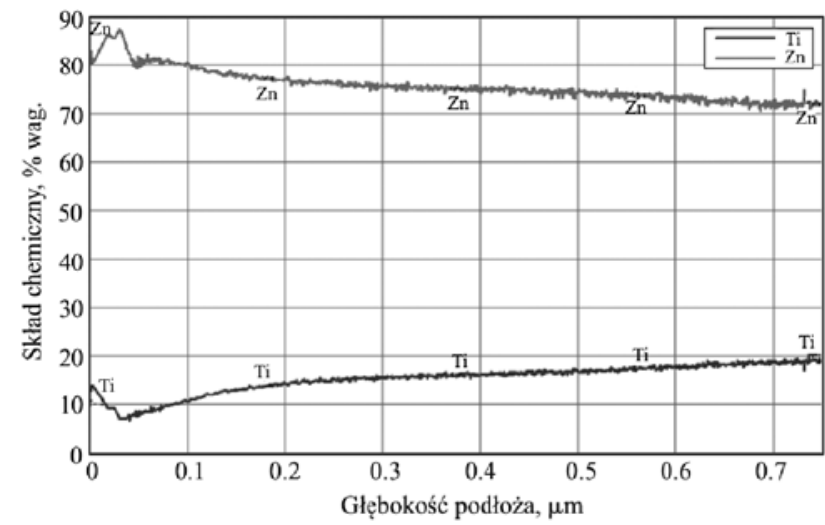

Rys. 1. Analiza profilu Ti i Zi po procesie z wykorzystaniem topnika F60T (zawierającego $\mathrm{ZnCl}_{2}$ ) na podłożu tytanowym

Fig. 1. Profile analysis of melted F60T flux (with $\mathrm{ZnCl}_{2}$ content) on the titanium substrate

Uzyskane wyniki badań wskazują, iż jest możliwe otrzymanie powłoki cynkowej na tytanie przez redukcję chemiczną stopionego chlorku cynku (II). Ilość powstającego $\mathrm{Zn}$ jest dość znaczna i wynosi od $80 \%$ wag. na głębokości $0,1 \mu \mathrm{m}$ do $70 \%$ wag. na głębokości $0,7 \mu \mathrm{m}$ [13]. Wyniki analizy nie obejmują udziału innych pierwiastków wchodzących w skład związków topnika F60T.

\section{Badanie właściwości lutowniczych topnika}

Badania właściwości lutowniczych topnika wykonano wg klasycznej próby rozpływności. Jako podłoże (próbki o wymiarach 40 × 40 × 2,5 mm) zastosowano 
blachę tytanową Grade 2 wg ASTM B265. Spoiwem, którego rozpływność oceniano na materiale podłoża w obecności badanych topników, był srebrny lut $\mathrm{Ag}$ 245 (B-Ag45CuZn-665/745) wg PN-EN ISO 17672. Próbkę tytanową przed właściwym badaniem odtłuszczano acetonem oraz trawiono w mieszaninie kwasów $\left(\mathrm{HF}+\mathrm{HNO}_{3}+\mathrm{H}_{2} \mathrm{O}\right)$. Na podłożu tytanowym układano lut srebrny w ilości 0,2 g, a następnie na nim nanoszono topnik również w ilości 0,2 g. Blachę tytanową poddawano ogrzewaniu w podobnych warunkach jak w przypadku próbki topnikowej. Na rysunku 2 przedstawiono schemat stanowiska do badania rozpływności lutu, a na rysunku 3 pokazano widok lutowania tytanu pod osłoną topnika F60T.

Podczas wykonywania prób rozpływności oceniano wizualnie przebieg topienia topnika, czyszczenie chemiczne powierzchni płytki tytanowej przez topnik i jego aktywność chemiczną. Po badaniach rozpływności

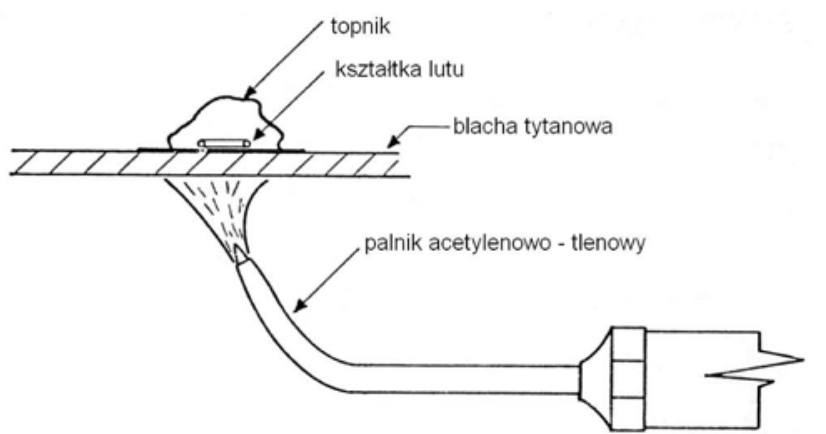

Rys. 2. Schemat stanowiska do prób rozpływności

Fig. 2. Station for spreading of flux testing

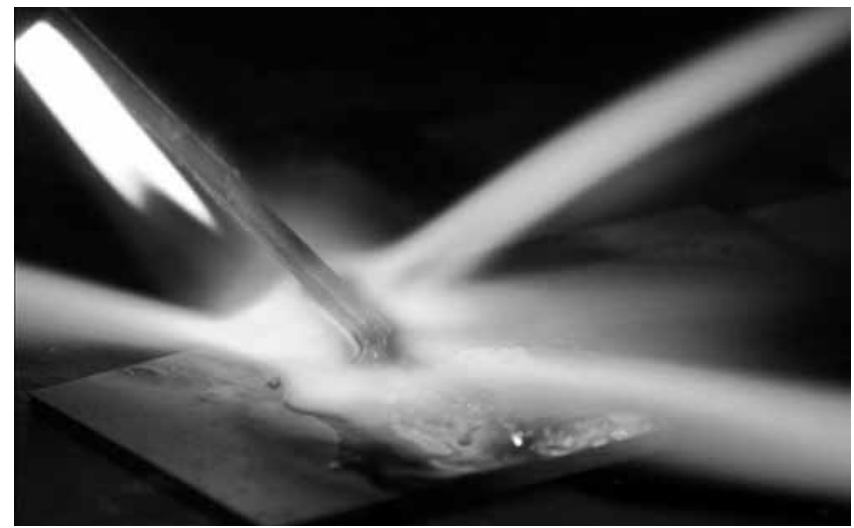

Rys. 3. Lutowanie twarde tytanu w powietrzu pod osłoną topnika F60T

Fig. 3. Titanium brazing in the air under cover of F60T flux

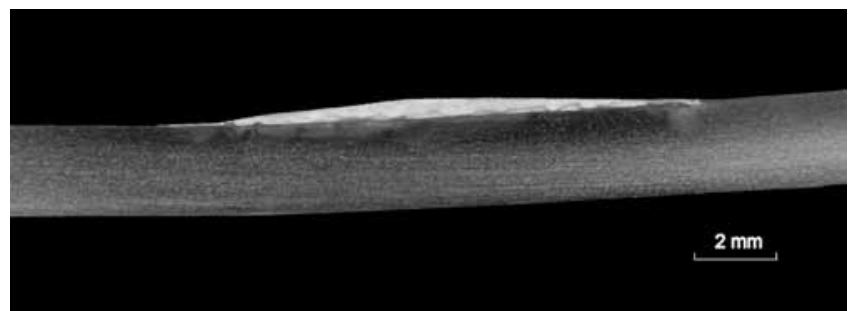

Rys. 4. Przekrój poprzeczny stopionego lutu Ag 245 na podłożu tytanowym

Fig. 4. Cross-section of $\mathrm{Ag} 245$ brazing metal on the titanium substrate
Tablica II. Wyniki prób rozpływności i kąta zwilżania lutu srebrnego Ag 245 (B-Ag45CuZn-665/745) na powierzchni tytanu (Grade 2) przy zastosowaniu topnika F60T

Table II. The test results of spreading and contact angle for Ag 245 (B-Ag45CuZn-665/745) brazing metal on the surface of titanium (Grade 2) substrate using F60T flux

\begin{tabular}{|c|c|c|c|c|c|}
\hline \multirow{2}{*}{$\begin{array}{c}\text { Oznaczenie } \\
\text { topnika }\end{array}$} & \multicolumn{4}{|c|}{ Rozpływność ${ }^{1)}$} & \multirow{2}{*}{$\begin{array}{c}\text { Kąt zwilża- } \\
\text { nia, } \theta,{ }^{\circ}\end{array}$} \\
\cline { 2 - 5 } & $\mathrm{P}_{\mathrm{S} r}, \mathrm{~mm}^{2}$ & $\mathrm{~S}_{\mathrm{p}}, \mathrm{mm}^{2}$ & $\mathrm{H}_{\mathrm{S} \mathrm{r}}, \mathrm{mm}$ & $\mathrm{S}_{\mathrm{H}}, \mathrm{mm}$ & 9 \\
\hline F60T & 156 & 7,5 & 0,39 & 0,02 & 9 \\
\hline
\end{tabular}

1) $P_{s ́}$ - wartość średnia powierzchni rozpłynięcia (z 3 pomiarów), $S_{p}$ - odchylenie standardowe powierzchni rozpłynięcia spoiwa, $\mathrm{H}_{\mathrm{sr}}$ - wartość średnia wysokości warstwy lutu po rozpłynięciu (z 3 pomiarów), $S_{H}$ - odchylenie standardowe wysokości warstwy lutu po rozpłynięciu

oceniano jakość i ilość powstającego żużla potopnikowego oraz łatwość jego usuwania.

Jako miarę lutowności zastosowano: wielkość powierzchni rozpłynięcia lutu (mierzoną za pomocą obróbki graficznej wykonanego zdjęcia próbki), wysokość warstwy lutu po rozpłynięciu (mierzona mikrometrem z dokładnością do 0,01 mm) oraz kąt zwilżania $\theta$. Na rysunku 4 pokazano przekrój poprzeczny rozpłyniętego lutu Ag 245 - na tej podstawie wyznaczono graficznie kąt zwilżania, wyniósł on $9^{\circ}$. Przeprowadzone pomiary rozpływności potwierdziły przydatność zastosowania topnika F60T do twardego lutowania tytanu w powietrzu (tabl. II).

Powstająca podczas lutowania ilość żużla potopnikowego jest niewielka i łatwa do usunięcia [12].

\section{Statyczna próba ścinania i badania metalograficzne połączeń tytanowych wykonanych z zastosowaniem topnika F60T}

Jako materiał podstawowy do badań zastosowano (podobnie jak w przypadku badań właściwości lutowniczych) blachę tytanową Grade $2 \mathrm{wg}$ ASTM B265, natomiast jako spoiwa użyto srebrnego lutu Ag 245. Powierzchnię próbek $z$ tytanu w postaci płytek o wymiarach 40 × 40 × 2,5 mm (próba wnikania lutu w szczelinę złącza zakładkowego, badania wizualne i metalograficzne) oraz pasków 100 x 10 × 2,5 mm (próba wytrzymałości na ścinanie) przed badaniami wytrawiono chemicznie w mieszaninie kwasów $\left(\mathrm{HF}+\mathrm{HNO}_{3}+\mathrm{H}_{2} \mathrm{O}\right)$, natomiast źródło ciepła w badaniach stanowił płomień typowego palnika tlenowo-acetylenowego z nasadką o wydajności $160 \mathrm{dm}^{3} / \mathrm{h}$ acetylenu.

Złącze zakładkowe (płytki ułożone poziomo, swobodnie bez docisku) wykonano, dozując lut ręcznie przy końcu zakładki. Szerokość szczeliny lutowniczej ustalała się w tych warunkach samoczynnie podczas wpływania lutu. Próba ta umożliwia ocenę właściwości kapilarnych lutu w obecności badanego topnika. Próbki po zakrzepnięciu lutowiny zanurzano w zimnej wodzie w celu całkowitego usunięcia żużla potopnikowego. 
Rys. 5. Lutowane złącze zakładkowe do statycznej próby ścinania Fig. 5. Overlap brazed joint for static shearing test

Na rysunku 5 pokazano polutowane złącze zakładkowe (szerokość zakładki $3 \mathrm{~mm}$ ), przygotowane do prób wytrzymałościowych.

Próbę statycznego ścinania wykonano na maszynie wytrzymałościowej Instron 4210 przy prędkości belki poprzecznej maszyny równej $2 \mathrm{~mm} / \mathrm{min}$.

Wytrzymałość na ścinanie tytanowego złącza zakładkowego wyniosła 163 MPa (średnia z trzech prób) [12]. Złom wystąpił w połączeniu lutowanym, zaobserwowano rozdzielenie złącza na granicy lutowiny z materiałem lutowanym.

Makrostrukturę połączenia lutowanego tytanu, o szerokości zakładki $5 \mathrm{~mm}$, pokazano na rysunku 6. Szerokość szczeliny lutowniczej w połączeniu wynosiła $0,05 \div 0,12 \mathrm{~mm}$.

\section{Wnioski}

Topnik wysokofluorkowy o oznaczeniu F60T do lutowania tytanu w powietrzu, wytworzony wg receptury opracowanej w Instytucie Spawalnictwa, charakteryzuje się dobrymi właściwościami lutowniczymi, potwierdzonymi pozytywnymi wynikami prób zwilżalności i rozpływności lutu srebrnego Ag 245 (LS45 wg PN).

Sumaryczna zawartość związków fluoru wchodzących w skład topnika do twardego lutowania tytanu lutem srebrnym $\mathrm{Ag} 245$ w atmosferze powietrza powinna zawierać się w granicach $60 \div 70 \%$ wag., w przeciwnym razie topnik nie zapewnia odpowiedniej zwilżalności i rozpływności lutu na podłożu tytanowym.

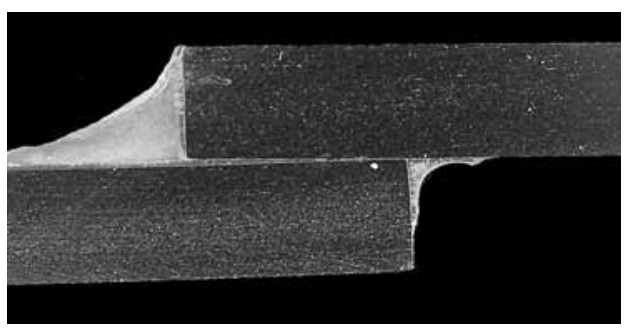

Rys. 6. Makrostruktura zakładkowego połączenia tytanu Grade 2 wykonanego lutem srebrnym Ag 245 pod osłoną topnika F60T, trawiono chemiczne odczynnikiem Adlera

Fig. 6. Macrostructure of overlap brazed joint of titanium Grade 2 with the use of Ag 245 brazing metal and F60T flux, chemical etching with Adler

Przeprowadzone badania metalograficzne pokazują, iż możliwe jest prawidłowe wykonanie złączy zakładkowych tytanu przy zastosowaniu klasycznego lutu srebrnego oraz specjalistycznego topnika lutowniczego F60T. Topnik ten umożliwia otrzymanie gładkiego lica lutowiny, bez niezgodności w jej objętości, przy szerokości zakładki $5 \mathrm{~mm}$ [12].
Przeprowadzona analiza profilowa warstwy metalu zredukowanego potwierdza mechanizm powstawania powłoki Zn ze stopionego chlorku cynku (II) $\left(\mathrm{ZnCl}_{2}\right)$.

Wykonane złącza zakładkowe przy zastosowaniu lutu Ag 245 oraz topnika F60T charakteryzują się dobrą jakością, stosunkowo dużą wytrzymałością na ścinanie wynoszącą średnio 163 MPa oraz niewielką pozostałością żużla potopnikowego. Otrzymany podczas badań topnik F60T umożliwił wykonanie połączenia zakładkowego o szerokości zakładki wynoszącej ok. $5 \mathrm{~mm}$ - lut szczelnie wypełnił złącze zakładkowe na szerokości całej zakładki, bez widocznych niezgodności lutowniczych.

\section{Literatura}

[1] Dobrzański L.A.: Metalowe materiały inżynierskie, WNT, Warszawa 2004

[2] Bylica A., Sieniawski J.: Tytan i jego stopy, WNT, Warszawa 1987.

[3] Dobrzański L.A.: Podstawy nauki o materiałach i metaloznawstwo. WNT, Warszawa 2002.

[4] Radomski T., Ciszewski A.: Lutowanie, WNT, Warszawa 1985.

[5] Radomski T., Ciszewski A.: Obróbka oraz łączenie tytanu i jego stopów, WNT, Warszawa 1968.

[6] Poradnik Inżyniera, Spawalnictwo, tom 1 i 2, praca zbiorowa pod red. J. Pilarczyka, WNT, Warszawa 2003/2005.

[7] Praca zbiorowa: Brazing Handbook. AWS, Miami, Florida 1991.

[8] Winiowski A., Majewski D.: Nowe topniki do lutowania twardego stali nierdzewnych oraz tytanu i jego stopów, Biuletyn Instytutu Spawalnictwa, $\mathrm{nr}$ 6/2008.
[9] DeCecco N. A., Parks J. M.: The brazing of titanium, The Welding Journal, nr 11/ 1953, s. 1071-1081.

[10] Winiowski A.: Lutowanie twarde stali nierdzewnej z aluminium i tytanem. Przegląd Spawalnictwa, nr 9-10/2006, s. 68 - 71.

[11] Messler R.: Joining of advanced materials. Butterworth-Heinemann, Boston 1993

[12] Winiowski A., Majewski D.: Badania nad topnikami o podwyższonej trwałości chemicznej do twardego lutowania tytanu, Sprawozdanie z zadania badawczego $\mathrm{nr}$ Gn-16/3, Instytut Spawalnictwa, Gliwice 2010.

[13] Winiowski A., Majewski D.: Badania fizyko - chemicznego oddziaływania topników z tytanem podczas lutowania twardego, Sprawozdanie z zadania badawczego $\mathrm{nr}$ Cc-52/2, Instytut Spawalnictwa, Gliwice 2011. 